\title{
Review of the Autobiography of Josef Svoboda, Canadian Arctic Climate Scientist
}

\author{
GEOFFREY WOOLLARD
}

Associate Scientist. Structura Biotechnology, Inc. Toronto, Canada

geoffwoollard@gmail.com

ORCID: 0000-0001-5440-4228

\begin{abstract}
In Wine from Raisins, Josef Svoboda, a Canadian arctic climate scientist, tells the story of his own life that encompassed 20th-century history and winds up facing the most important questions of the 21st century - questions about what we have learned from nature, what we have done to our environment and who we will become as we drift away from the natural world toward one immersed in our own technological creations. Readers of Wine from Raisins will glimpse the world through the eyes of Svoboda, who combines scientific training with a contemplative gaze.
\end{abstract}

Keywords: geology; Czechoslovakian communism; relationship of the human person to nature.

In Josef Svoboda's autobiography Wine from Raisins, A Life Transformed through Communist Gulag to Canadian Arctic by Josef Svoboda (Novalis, softcover, 240 pages, \$27.95), a Canadian arctic climate scientist tells his own life story that encompassed 20th-century history and winds up facing the seminal questions of the 21 st century - questions about what we have learned from nature, what we have done to our environment and who we 
will become as we drift away from the natural world toward one immersed in our own technological creations.

This autobiography is summarized in the radio interview he gave in the spring of 2010 to a Czech Radio Channel.

A boy from Moravia survived the Second World War. Then, as a student, he was arrested by the post-war Communist regime and spent almost nine years in various prisons and concentration camps, his life seemingly ruined in the process. But he endured, succeeded in finding freedom on a different continent and, at the end and with God's help, became a recognized Arctic tundra scientist. (p. 7)

The book follows Svoboda's phases of life, pre- and post-gulag, and stands as living proof "that nothing is ever lost in life; that it is possible to start anew, even after age 40.” (p. 7). This epic tale, packed full with gripping anecdotes, can deliver a dose of historical realism to any romantic vision of life behind the iron curtain, and light a fire in the belly of newcomers to Canada who want to hit the ground running.

Svoboda's Life Transformed Through Communist Gulag to Canadian Arctic is great nourishment for blossoming scientists. Wine From Raisins will help the mature reader fly over a midlife crisis like an arctic bush plane flies over half-thawed swamps before touching down on solid ground. It makes light evening reading, and at 240 pages this book can be finished in a few weeks. It contains raw stories and is suitable for those teenagers who are already aware of cultural problems and the line of good and evil running through the human heart.

From the first pages, Svoboda's golden heart shines through as he imparts his sage advice. "The most important thing in life are relationships" (p. 8). He lived (and continues to live) a happy family life and looked up to his father, a locomotive engineer, who delighted his boy's heart by letting him blow the steam whistle (p. 13). His love of nature was planted by his Scout leader and watered by the poems and literature of Ernest Thompson Seton, Thoreau, Ruskin and Kipling.

However, his idyllic boyhood is darkened by the clouds of the Nazis and the Russians and Rumanian armies that replaced them after the Second 
World War. The reader who is hungry for adventurous anecdotes will have more than his fill by the war years, privations and assaults against human dignity he endured as a political prisoner.

One anecdote is too lively to pass over in this review. As a teenager his father woke him up and enlisted him to rescue their stolen horse Bobik.

I jumped out of bed and got dressed. Sure enough, the barn door was open and two Rumanian soldiers were leading our horse across the backyard. "Put your rifle on your shoulder so they see you're a militiaman," my normally cautions father said to me. [... T] he soldiers made it to the nearby forest with our horse. I followed them. They stopped in a clearing and began transferring the halter from their weak nag to our well-fed Bobik. At that moment, the spirit of all the westerns I had ever read awoke in me. I stepped out of my sheltered place in the woods, aimed my gun at the two war-experienced soldiers and shouted: "Hands up!” The surprised soldiers actually did what I asked. But what was I to do now? “That's my horse! It's private! Give it back to me!" I called out. I lowered the gun. The soldiers jumped behind the horse, grabbed their rifles, and aimed at me. I was in trouble. Fortunately my guardian angel was with me. (p. 21)

Svoboda was only in university for a short time before he was arrested at the age of twenty. He would spend his twenties in the forge of the gulag, for picking up a sealed envelope from one agent of political resistance and delivering it to another. The dizzying transfer between prisons and labour camps (Mírov, Ostrava, Bory, Pankrác, Ilava, Leopoldov, Kartouzy, Valdice, Praha, Mariánská, Barbora, Mikolaj, Rovonost), ends with his release in 1958, after 8.5 years.

This dark section of the book is filled with uncooked life stories, which are related clearly and concisely. Svoboda takes stock of his life and the trauma from the past resolves through the intertwining of providence and his free choices. Adversity served as a forge for Svoboda's strong willed character. For Czech nationals and Czechophiles, the churchmen he meets in the Mukl's Vatican of Leopoldov may have particular interest. This period of formation, in which he was formally taught courses in philosophy and theology, influenced his intellectual approach to science and religion. The 
bishops and prelates he lived with behind bars "carried on very lively discussions about the scientific perception of creation, evolution and Darwinism. Teilhard de Chardin was still an unknown name, but his ideas were already circulating in the Leopoldov Vatican" (p. 94).

Svoboda was released and able to rebound and grow stronger a few months shy of his 29th birthday.

During all those years, I had had the incredible honour of meeting the cream of our nation. I felt extremely grateful for this experience. Although I had not chosen to be in prison and would not return there voluntarily, I would never renounce that experience and would not have changed it for anything. Thanks to God, I had survived and it was all worth it. Nowhere else would I have been able to receive such a thorough physical, moral and even professional formation - not in the army, not in university, not even in the seminary. (p. 107)

His attempts to fit in with society, make up for lost time and finish off his studies were blocked. He was a blacklisted political prisoner, and unwilling to roll over to corrupt public figures abusing their authority. "I have a mild nature, like my mother. Yet there is a touch Svoboda lying not far below the surface, and if provoked, as happened [...] while serving my long sentence under the cruel prison guards, it rises up quickly" (p. 118).

However, through hard work, determination, persistence and patronage Svoboda eventually moved forward in his professional vocation and landed a research position at the Academy of Science in Brno. His description of a wetland research location in Moravia shows his love of nature through a scientist's eyes:

The region has an interesting geological and cultural history. Long before Africa was connected to southern Europe, this area was covered by the Mesozoic sea. The collision of the two continents raised all of Central Europe, the interior sea flowed away and the seabed became covered with vegetation. Not entirely, however. Residual lakes remained in some areas after millions of years, their water, while completely fresh, retained some sea salt that had been left in the ground. (p. 132) 
Svoboda's flight to Canada as a refugee was fortuitous and spontaneous. He had been pondering it for a time, but he only had a few days to finalize his decision once the circumstances presented themselves. He hit the ground running in Canada, and never looked back. After landing in Ontario he finished off his degree at the University of Western Ontario, with due regard given to his personal story.

They went through my documentation, and after a short consultation they said that considering my previous education, credits and age (I was 40), I should do five full courses. If I completed them with good results, I could graduate the following spring. This was amazing; Canadian universities normally require at least two years of residency. I took a summer course and started four more courses in the fall of 1969. I wrote my last exam in April and obtained my Bachelor of Science degree with honours in May 1970. It was a tough year. The next month, I began the PhD program and the University of Alberta in Edmonton, and three years later, in June 1973, before I had the chance to defend my thesis, I was offered a position as assistant professor at the University of Toronto. (p. 147)

The author spent decades in the Canadian Arctic, during summer research trips. He relates scientific discoveries with rich detail, showing how deeply these moments are engraved in his memory.

The bare terrain of the High Arctic, almost free from higher plant life, is for a geologist like an open book of the Earth's history. From the Archean rocks, with are over three billion years old, all the way to the Quaternary the era of the last two to three million years old, it is all in the palm of one's hand. Moreover, with the rock already broken by frost in places, all one had to do was to bend over and look down. [... C]ontours of ancient algal coating [...] had been periodically covered by a new layer of fine mud, which solidified and preserved it. Over the centuries, this process was repeated annually. Once the structures, like three rings, had fossilized, they turned into "castings" of primordial coastal life. (pp. 156-157)

The author provides sufficient scientific context, without being pedantic, that enables the reader see the beauty of the arctic with the heart of Josef Svoboda. 
[W] stood on the interface of geological time, when the originally incandescent surface of a young planet Earth cooled enough to retain water in its reservoirs for the first time. Until that point, all the water of the later oceans was floating in the atmosphere in the form of thick, heavy clouds. But time passed, the Earth cooled, and finally the first rains arrived. Let us imagine an earthy sauna with hot showers when, for millions of years, the sky stormed without a break and continents exploded with countless volcanoes. Hot water streaming along the planet's surface dissolving erupted rocks and washing away the dissolved substances into the abyss of the first oceans. The first nutritious soup was being cooked, out of which life soon emerged. Insoluble silica sands were washed down into shallow basins. That is how the primordial sediments originated; the silica crust on which we were walking was the uplifted precious residue from one of them. Subsequent orogenic processes added further layers, but the tireless erosion that continued, and even later the moving glaciers, scraped nearly everything back to the Pre-Cambrian rock bone. (p. 157-158)

Precious personal correspondence is reprinted in this autobiography, such as a letter of Cardinal Štěpán Trochta, Bishop of Litoměřice that Svoboda received in 1970 while in the Arctic. Cardinal Trochta imparts a deeply spiritual message on approaching God through nature.

If our approach to God is like the investigation of an object, we can become deists. But believing in a Christian way is possible only when we stop examining him from the lofty position of our critical reasoning, holding him captive as a subject of our interest in science, standing lower than human beings on the scale of value. Hoping and loving God above everything is possible only when we begin looking up to him with the humility of a creature towards the Creator and with the tenderness and love of a son towards his father.

[...] As soon as man takes an objective attitude with his heart towards God, this attitude automatically carries over to people. Today people are conceived of as things, in a scientific way. Unfortunately, this means that they are detached from all personal love, astonishment, respect, and soulfulness. [...W]e need to be understood, pleased and respected; we need to love, be amazed, and we need to worship. 
[...] Therefore when you are in that virgin nature, be sure not to focus only on research. Let the living God speak to your heart through nature, and experience that not-yet-deformed, mysterious language with which your Intangible Father will speak to you through nature. I think you can experience there truly life-giving prayer - that great presentiment of Someone and the indescribable amazement of the human heart over His work and power that has not been expressed in words yet! Do not miss this chance for your spiritual life. We people have actually spoiled a very small piece of the entire universe. Our tragedy and punishment, however, lies in the fact that we spend practically all of our time on this spoiled patch. (pp. 160-161)

Svoboda paints a captivating vignette of the Arctic, including not only the geology, botany and zoology - but also the anthropology of the Inuit. A French Oblate missionary priest passed on this story when asked about the hardest thing for him as a young educated European living in the Arctic.

The freezing cold, frostbite, primitive conditions, insects, even hunger - all these were bad, but the worst things for me was the lack of privacy. Wherever I went, someone always followed me and asked me what I was doing and why. I had peace only in my sleeping bag. One day I took refuge on a small island, where I wanted to spend some time alone. I put up a tent and was happy to be enjoying some freedom. Not even a day had passed when a dog team arrived with an old Inuk behind the sled.

"Are you okay? Are you sick?"

“No, I’m just fine."

"Are you angry at us Inuks?"

"Not at all, on the contrary."

"So why did you leave us?"

I assured him that I just needed to be alone for a while and that I would come back. The Inuk left and I quickly moved to another island so they could not find me so easily. The next day three dogsleds arrived. I decided to go back with them, and gave up my attempts to find solitude. Their intuition fold them there must be something wrong with someone who voluntarily separates; be must be in danger. (p. 182) 
Svoboda was deeply moved by these French Oblates, who, within two generations, made notable inroads towards the evangelization of the North. "Over 50 of these Oblates had come to our country, and none had deserted. They helped the primitive hunters as much as they could at a time of great change. They spread the Goods News in the local language, Inuktitut, and made the Christian Bible accessible and easily readable in the syllabic writing system" (p. 190). He also relates ongoing challenges to the Northern missions, who suffer for lack of priestly attention in a culture where people have difficulty celebrating celibacy as a vocational call to availability from God.

Svoboda's contemplative gaze at nature spread to his students, and the northern silence provided ample space for questions at the boundary of science. The summer sun did not set on these questions, which are cultivated by a scientific mindset, but require more to yield the fruit of wisdom.

Students who went through this experience become enthusiastic protectors of nature, especially of the uninhabited Arctic, the cleanest and most original world one can imagine. After living in the pristine world without a radio, television or even a portable audiocassette player [...], people spoke to each other more. Our originally incongruous group was transformed into a true community. In our conversations, we discussed fundamental questions: How did everything originate? Why are we here? What is our mission? These matters are compelling for young people, and they enjoy the search for answers. During the workday there was not much time for debate, but after supper, we often ventured back into the tundra. These evening walks under the midnight sun offered a special setting for talks and sharing, especially in the stunning landscape of the fiord. (p. 204)

Svoboda's relationship with nature was not stunted by childhood Disney films, but was mature and realistic. He humbly listened to the silent words spoke between all living things, and developed a seasoned sensitivity to the way energy and change flows through the biosphere. He did not come to the Arctic with all the answers, but learned them from fully living his time up there.

Once or twice, I offended some of my students. Foxes used to roam around our camp. They were always hungry, the camp smelled good to them and they liked 
to sniff around for a bite to eat. Their den was not too far away, and every year a litter of pups would play in front of it. Their parents took care of them, but the family was large and food was scarce. The strongest pup always grabbed the biggest bite, while the weakest one got weaker and eventually died, only to be eaten by its siblings. This would happen throughout the summer until there was only one pup left from that year's litter. Maybe it would survive the winter, maybe not, but on average only two pups of about 30 born to the same parents grew old enough to replace their parents. That's how it is with animal species; otherwise, the ecosystem would overpopulate and crash. That happens sometimes, but overall a dynamic equilibrium is maintained in balanced ecosystems. (pp. 223-224)

The mysteries of creation reach a whole new level of depth and intensity in the human person. The cycle of life and the law of return can be raw; but when the sting of death lashes out it can leave wounds. In the final pages Svoboda pours out his father's heart and writes a touching portrait of his beloved son Andrew who passes away unexpectedly, just as his career as a composer is blossoming. Svoboda humbly bows his head with knees shaky, but his feet on the solid rock of a supernatural outlook.

His sudden death opened up the eternal day for our Andrew, but it imposed an endless night on us, his family, from which we were unable to awaken for a very long time. The question "Why?" might have been in order, but we did not ask. Who am I to challenge fate or question God? Lewina [Svoboda's wife and Andrew's mother] was desolate and had no strength left to ponder anything. Mater dolorosa ... juxta crucem ... lacrimosa. The grieving mother stood beside the cross, weeping... (p. 236)

I hope this noble scientist and human being has another writing project up his sleeve, perhaps reflecting on the precious wisdom of past generations or peering into the future as some of us attempt to reestablish harmony with the natural world.

Since my retirement I have remained active professionally, and for many years I have served as a lay catechist in our Burlington parish. I maintain extensive 
correspondence and spend hours at the computer each day. As a biologist, I continue to be interested in origins: the beginnings of the world, of life and of future humanity. Philosophically, I would like to figure out where we are heading. Where is this technological civilization taking us? Will it transform human beings beyond recognition? What are the prospects for human survival in the distant future? I have published articles and treatises on these subjects. (p. 238)

I recommend this book to readers interested in exploring these themes through the luring lens of a long life story. Before Svoboda penned this book, he had already written it with the deeds of his courageous and contemplative life. Wine from Raisins is strong drink to light a fire in the belly, and a salve to sooth the soul. It encourages us to write a biography with the deeds of our own lives.

\section{References}

Svoboda, Josef. 2017. Wine from Raisins: a Life Transformed through Communist Gulag to Canadian Arctic. Toronto: Novalis. 